\title{
(1)
}

\begin{tabular}{|l||c|c|}
\hline \hline Received 14.02.2020 & & JOTS \\
$5 / 1$ \\
\hline \hline Accepted 02.01.2021 & Review & $2021: 205-211$ \\
\hline \hline Published 10.01.2021 & & \\
\hline
\end{tabular}

\section{Sertkaya, O. F. \& H. Uzuntaş. Dede Korkut'un Günbed Yazması Üzerine Araştırmalar ve İncelemeler, İstanbul: Bilge Kültür-Sanat, 2020, ss. 173, ISBN: 978-605-7931-98-6}

\author{
Aslıhan HAZNEDAROĞLU* \\ Düzce University (Düzce/Turkey) \\ E-mail: aslihankaragoz@duzce.edu.tr
}

2019, kültür dünyamızda tam anlamıyla bir Dede Korkut y1lı olmuştur. Dresden ve Vatikan yazmalarının keşfinden nice yıl sonra yeni bir yazmanın daha ortaya çıkması büyük bir heyecan uyandırdı, tartışmalar yapıldı ve bir yayın yarışı başladı. Yeni yazmayı tanıtan ilk üç çalışma ülkemizde 2019 Haziran ayı içinde yayımlanmıştır. Bugün ise Azerbaycan ve İran'daki çalışmalarla birlikte yeni yazma ile ilgili çalışmaların sayısı ona ulaşmıştır. Bu yayınların takip edilip karşılaştırılması, bu yeni araştırma sahasının önemli bir gündemidir.

Yeni bulunan yazma ile ilgili, transkripsiyon, metin çevirisi ve şerh dişında bir çalışma olarak Sertkaya ve Uzuntaş'ın incelemesi, kitap boyutuna ulaşan ilk çalışmadır. Artık elimizde, ilk dört yayını görüp değerlendiren ve yazmanın filolojik yapısı üzerine eğilen bir çalışma mevcuttur.

Bilge Kültür Sanat yayınları bünyesinde okuyucuyla buluşan kitabın saman sarısı rengindeki kapağı, okuyucuyu yazmanın sarargın dünyasına taşıyacaktır. Ön kapaktaki görselde, söz konusu yazmanın ilk sayfalarında yer alan ve müstensihin 2. ve 3. soylamayı takdim ettiği kırmızı mürekkepli satırlar görülmektedir. Araştırmacıların da dikkat çektiği üzere, bu takdim satırları diğer sayfalarda yoktur, ama bölümlerin arasına başlık yazılacak bir boşluk

ORCID ID: 0000-0002-0778-6101. 
bırakılmıştır. Çok itinalı olduğu anlaşılan müstensih, nedense kırmızı mürekkebini bir daha kullanamamış, sözü eksik bırakmıştır.

Bu soylamada Dede'nüy müddeâsı budur ki ve Dede'nüy bu soyda matlâbı budur $k i$ şeklinde tekellüfü sözlerle başlayan iki arasöz, sözlü gelenekten gelen bir metnin kitabî bir dil ile takdim edilişini örneklendirir. Kitabın adının bu iki takdim arasına alınması, yayınevinin tasarımdaki inceliğidir.

Prof. Dr. O. F. Sertkaya, Dede Korkut metinleri üzerine çalışmayı, hocası M. Ergin'in kendisine bir vasiyeti (2020: 9) olarak benimsemiş, bu sahadaki birçok sorunu çözüme kavuşturmaya çalışmıştır. Bu yıl Dede Korkut kitaplığına üçüncü eserini de eklemiş olan yazar, yeni bulunan yazmanın da ad koyan araştırmacılarından olmuştur. Prof. Dr. A. Sertkaya'nın doktora cübbesini giydirdiği ve Çağatayca Seyfe'l-Mülûk ve Bedî́ül-Cemâl Hikâyesi'nin nâşiri olan Dr. H. Uzuntaş ise bu kitapla Korkutşinaslar arasına katılmaktadır.

Eser, Sertkaya'nın ve Uzuntaş'ın yeni yazma eksenindeki makalelerini ihtiva etmektedir. İlk yazıda ilk dönemlerde çokça konuşulmuş olan bir konuya, yazmanın bulunuşu ve bilim dünyasına duyuruluşuna değinilmiş ve Y. Azmun'un çalışmasının öncülüğ̈̈ nazikçe vurgulanmıştır.

Eserde yazılar belli bir sıraya konulmuş izlenimi vermese de biz bu yazıları muhtevasına göre üç grup olarak düşünebiliriz:

1. Yazmanin tanitılmasina dair yazılar.

2. Yazma hakkındaki yayınlara dair yazılar.

3. Yazmanın söz varlı̆̆ı ile muhtevasına yönelik yazılar.

\section{Yazmanın Tanıtılmasına Dair Yazılar}

Yeni bulunan yazmayı tanıtmaya, yazmanın dilimiz ve tarihimiz içindeki yerini teşhis etmeye yönelik olan yazılar, eserin belkemiğini oluşturur. $\mathrm{Bu}$ yazıların alanın öncü bir ismi tarafından yazılması elbette etkisini arttırmaktadır.

Temmuz 2020 baskılı eser, 12-13 Haziran 2020'de düzenlenen Dede Korkut Bilgi Şöleni'nin en taze bir yankııını taşımaktadır. Bu yankıyı en başta sunuş bölümünde, sonra da eserin son yazısında görmekteyiz.

Bilgi şölenine, üç gün süren çalıştayın davetlisi olarak katılan Sertkaya, üzerinde uzlaşılmaya çalışılan konular hakkındaki fikirlerini yansıtırken, yapılan 


\section{J(৫)}

tartışmaların kısa bir özetini de vermektedir. Deli Dönmez'e Ad Verme olarak isimlendirilen çalıştayda, Dede Korkut'un bulunan bu yeni yazması hakkında en çok şu iki soru üzerinde durulmuştur:

1. Yazmanın adı ne olacak?

2. Yazmada kaç boy vardır?

Yazmanın adı meselesi, kitabın sunuş yazısında ele alınmış, kitabın adıyla da duyurulmuştur. Toplamda 9 farklı şekilde isimlendirilmiş bu elyazması için çalıştayın sonuç bildirisinde, Türkmen Sahra ve Günbedikavus adları kullanılmıştı. Sertkaya, Günbed adına olan itirazı kendine has üslubuyla cevaplar ve bu yüzden ortak imzalı da olsa bu yazıda hocanın sesi işitilir: Bu sıralarda Türk televizyonları Covid-19 virüsü dolayısıyla Amerika’ya bağlanıyorlar. Amerika Birleşik Devletlerine değil. Dolayısıyla İran'daki şehir adının Günbed şeklinde söylenmesinde bir eksiklik olmadığı anlaşllyyor. (s. 10). Eserde yer yer Günbed (Türkmen Sahra) şeklinde ikili bir kullanım gözetilmiş olsa da, kitabın adına Günbed'in alınması net bir tavır olarak değerlendirilebilir.

Yazmada kaç boy vardır? (veya boy var mıdır?) Daha önce bu konuda Azmun'un yazmanın "iki boy"dan oluştuğu fikrini desteklemiş olan Sertkaya, kitabın tarihsiz olan son yazısında (s. 161) konuyu özel olarak yeniden açar. Tartışmanın taraflarını sıralar. Bu kez "ikinci boy" olarak konuşulan metindeki savaş sahnelerini ele alır ve "Salur Kazan'ın Aras Suyu ile Kars Kalesini aldığı" anlatının kısa da olsa bir boy olarak kabul edilmesi gerektiği kanaatini yineler.

Yazma hakkında bir de "soylama sayısı" meselesi vardır. Bu meseledeki ihtilafa Sertkaya, Azmun ve Ekici yayınlarını karşılaştırırken değinmiştir (s. 2728).

Dresden ve Vatikan yazmaları için neredeyse gündem olmamış bir konu, bu yazma için büyük bir ihtilaf konusudur ve bütün bu "boylama - soylama" (hatta isim) tartışmalarını başlatan da, müstensihin bir sebeple ortadan kaybolan kırmızı mürekkebidir. Başlık olmadığı için Dede'nin matlabı bilinememekte, sözlü gelenekten gelen bir metin, birçok defalar olduğu gibi, bilimsel sınıflandırma gayretini zora sokmaktadır. Soylama sayısındaki ihtilaf, sayfa numaralandırmada bir birlik olmaması kadar zorlayıcı bir meseledir. Bunca 


\section{ग(৫)}

ihtilafa rağmen Buruldum-ise diye başlayan soylamanın mevcut bütün çalışmalarda "17" olarak numaralanmasını büyük bir talih olarak görebiliriz.

“Ortak bir çözüm” hedefine tam ulaşılamasa da Dede Korkut Bilgi şöleni'nin farklı fikirlerin tanınıp değerlendirilmesine olan katkısını burada anmalıyız. Şölenin çok önemli bir katkısı da, yeni yazmaya dair bilinen ilk 4 yayından sonraki çalışmaların Türkiye'deki araştırmacıların bilgisine sunulması olmuştur. $\mathrm{Bu}$ şölende haberi verilen yayınlar, Günbed yazması yayın listesine eklenmiştir (s. 10).

Elimizdeki eserin teşhis edici bir diğer yazısı Dede Korkut Kitabı'nın Kaç Yazma Nüshası Var? (s.101) başlı̆̆ını taşır ve bu yazmaya neden Dede Korkut Kitabi'nın "nüshası" denilemeyeceğini izah eder. Nüsha, varyant, versiyon ve paralel metin kavramlarını açıklayan Sertkaya, Dede Korkut Kitabı'nın Ankara'da bulunan 22 sayfalık yazmasına ve Vatikan yazmasına varyant, Günbed yazmasına ise paralel metin demektedir.

Kitapta okuyucuya sunulan özel bir belge, Dresden yazmasını gören ilk Türkleri gösteren kütüphane kayıt defteri sayfasıdır. Bu deftere 19 Nisan 1927'de A. Caferoğlu'nun, üç buçuk yıl sonra 10 Aralık 1930 'da da R. R. Arat'ın adı işlenmiştir. Burada Sertkaya hocası M. Ergin'in Türkoloji Müzesi için bıraktığı miras olarak Dresden elyazmasının siyah beyaz fotoğraflarını ve elyazılı metin transkripsiyonunu da yâd eder (s. 104- 105).

\section{Yazma Hakkındaki Yayınlara Dair Yazılar}

Eserde iki tanıtma yazısı yer almaktadır. Y. Azmun'un Dede Korkut'un Üçüncü Elyazması eseri hakkındaki yazı (s. 17-24) örnek bir değerlendirme metnidir. Burada 17. soylama ile ilgili önemli bir karşılaştırma da yer almaktadır. Yazıda bu soylamanın olduğu iki sayfaya ve bu metnin transkripsiyonuna yer verilmiştir. Salur Kazan'la ilgili en önemli metinlerden olan bu metne yazar kitapta birkaç defa dikkat çekmiş ve bir yerde de bu metin için "Gazan soylaması" tabirini kullanmıştır. Sertkaya'nın tabiriyle, Kazan'ın önceki adının Deli Dönmez olduğunu açılaması her şeye değer (s. 14). Bu soylama için verilen metin, Azmun'un yayınıyla tam olarak örtüşmemektedir.

Sertkaya'nın "Dede Korkut soylamalarının birçoğunun ve belki de hepsinin hece vezni ile dörtlükler halinde söylendiği ve yazıldığı” (2020: 339) düşüncesini göz 
önünde bulundurduğumuzda, bir soylamalar kitabı gibi duran Günbed yazmasının manzum yapısı çetin bir sınama konusu olacaktır. Sertkaya, soylamaları manzum olarak düşünmedeki tercihini 17. soylamada göstermiştir. Yazarın bu soylamada "serbest hece vezni” olarak (s. 18) belirttiği ölçü, yer yer (Yeddi başlı yer evreni / Olubanı kuyruk çaldım veya Ala sayban çatılmışdı / la'li çakır süzülmüşdi gibi) 8'li ölçü (4+4) olarak işaretlenebilir. Metnin belirli bir nazım birimine uyarlanamazlığı ise zor bir meseledir.

Eserde yer alan diğer tanıtma yazısı, R. Asker ve onun başkanlığında hazırlanan Dede Korkut yayını üzerinedir (s. 83-86). Yeni bulunan yazmanın Azerbaycan'daki ilk yayını hakkındaki bu yazı, erken bitmektedir.

Eserin önemli bir yönü, yeni yazmanın okunuşuna dair düzeltme çalışmaları ihtiva etmesidir. Dede Korkut'un Günbed Yazmasının Azmun ile Ekici Yayımlarında Düzeltmeler ve Tamamlamalar (s. 25-48) başlıklı yazıyı Sertkaya, Ercilasun ve Gülensoy tarafından yapılan değerlendirmelere paralel bir inceleme sunar. Günbed yazmasıyla ilgili ilk yayınlardan hemen sonra uzun bir düzeltme listesi oluşmaya başlamıştır. Dresden ve Vatikan okumaları üzerine bugün bile düzeltmeler yapıldığı düşünüldüğünde bunun son derece beklenilesi bir durum olduğu açıktır.

Eserdeki düzeltme ve anlama çabalarının özellikle ilk iki yayını (Azmun ve Ekici'in yayınlarını) dikkate alarak yapıldığını söyleyebiliriz. Bugün Günbed yazmasını değerlendirmek, mevcut on yayınla birlikte, ortaya konmuş olan bu düzeltme çalışmalarını takip etmeyi de gerektirmektedir. Hatalardan en çok arındırılmış bir yayına ulaşmak, bu tür çalışmaların ortaya koyduğu birikimle sağlanacaktır.

\section{Yazmanın Söz Varlığına ve Muhtevasına Dair Yazılar}

Yeni yazmanın Dede Korkut araştırmacılarına tanıdığı yeni bir imkân vardır. $\mathrm{Bu}$ da Günbed Yazmasinin Önceki Dede Korkut Yazmalarindaki Bazı Okumaları Düzeltmesi (s. 47-54) başlıklı, ortak imzalı yazının konusudur. Bu yazıda Dede Korkut deyimlerinin belki de en merak edileni olan çaya (- çapa) girse çalımlı çal karakuş erdemli (- kaynaklı) sözüne de 1şık tutulmuştur.

Dede Korkut'un Günbed Yazmasinda Geçen 50 Moğolca Kelime (s. 55-82) başlıklı yazıda, yazmada geçen kırk sekiz kelime ele alınmaktadır. Bu kelimeler arasında 


\section{J(৫)}

kurban, öleng, torkay, tumçuk kelimeleri Türkçeden Moğolcaya geçip Moğolcadan Türkçeye dönen; karangu, kaplantu ise Moğolca ek almış "hibrit" kelimeler olarak işaretlenir. Çeçek-çiçek, çöl kelimeleri müşterek kültür kelimeleri sayılarak listeye alınmaz. Bu listede ayrıca aka 'ağa', karı 'ön kol' gibi daha önce Türk diline ait olduğu düşünülmüş kelimeler de Moğolca kelimeler olarak ele alınmıştır. Bu yazının, Türkçenin söz varlığının araştırılmasında büyük emek sahibi olan, Osmanlıcada Moğolca Kelimeler makalesi yazarı "Prof. Dr. Osman Nedim Tuna'nın aziz hatırasına" ithaf edilmesi dikkate değer bir ayrıntıdır.

Dede Korkut "Gayıbdan Dürlü Haber Söyler miydi?" (s. 87-100) başlıklı yazı, Sertkaya'nın önemli bir karşılaştırma çalışmasıdır. Dresden yazmasının mukaddimesinde geçen “Korkut Ata'nın "Oğuz'un evvel kişisi olduğu, gayiptan dürlü haberler söylediği ve yüce Tanrinın (söyleyeceklerini) onun gönlüne ilham ettiği" şeklindeki ifadeler, Dede Korkut geleceği biliyor muydu sorusunu sordurmaktadır. Burada yazar Berlin'deki Oğuznâme-i Türkî ve Tatarca Darb-ı Meseldir başlıklı yazmada geçen metni, Günbed yazmasının 18. soylamasındaki paralel metin ile karşılaştırır. Her iki metnin transkripsiyonuna ve çevirisine yer verir.

Uzuntaş'ın Günbed Yazmasında Fauna (s.109-159) adını taşıyan makalesi, yazmanın söz varlığına dair önemli bir dikkattir. Uzuntaş, burada yazmada geçen bütün hayvan türlerini, yazılışı, okunuşu, cinsi, Latince adı ve kökeni ile tablolaştırarak tanımlamış, bu adların metinde geçen örneklerini de sıralamıştır. Türlerin Latince adları için yer yer Karahan'ın makalesinden yararlanılan bu çalışmada, bazı kelimeler üzerine dipnotlarda açıklayıcı bilgiler yer alır. Yazıyı besleyen bu dipnotlarda kazaguç, kaybatan, ağayıl gibi kelimeler üzerine yapılagelen tartışmaların da genel bir değerlendirmesi sunulmuştur. Yazının sonunda yazmada geçen 90'dan fazla hayvan cinsini gösteren bir şemaya ve sayısal verilere yer verilmiştir.

Yazmadaki kelimelerin çözülmesi metnin anlamı üzerine yeniden bir daha düşünmeyi gerekli kılacaktır. Sözgelimi erkeç kelimesinin “iki yaşında iğdiş edilmiş erkek keçi” anlamını bulmak, âyet âyet arı Kur'an din erkeci ifadesini aydınlatamaz. Metinde bunun gibi açıklığa kavuşmayı bekleyen pek çok soru vardır ve bu çalışma bunları daha da görünür kılmıştır. Artık ilk tartışmaları atlatıp bir suhûlete de ermiş olduğumuza göre, metnin anlamı üzerine daha fazla düşünebilir, çözümlemeyi dert edinebiliriz. Dil sahasında yapılan çalışmaların 
Dede Korkut'u bir düşünce konusu olarak ele almak hususunda yol göstericiliği vardır.

Eserdeki yazılar, sunuş ve son yazı hariç, yayımlanmış makalelerdir. Metinler üzerinde yayınevinin nerdeyse hiçbir tasarrufta bulunmadığ anlaşılacaktır. Eserdeki iki yazının Facebook yazısı olarak sunulması, Sertkaya'nın bu mecradaki paylaşımlarını bilmeyenler için şaşırtıcı gelebilir. Akademiden hiç kopmayan bir bilim insanının sosyal medyaya yüklediği anlamı ifade eden bu paylaşımlar içindeki birçok hatıra ve eleştiri yazısı da kitaplaşmayı beklemektedir.

10 bölümden ve dizinden oluşan eser, “Üç otuz on yaşasın” temennisiyle 70. yaşının kutlaması olarak "Dede Korkut'un ruhuna vakıf olup romanın yazan, akademik, rektör, doktor Profesör Kamal Mehdioğlu Abdulla'ya" ithaf edilmiştir.

Elimizdeki bu çalışma, söz fazlası içermeyen, arı duru bir dille yazılmış, önemli konularda söylenmesi gereken sözü söyleme amacında, dikkat isteyen bir çalışmadır. Dede Korkut Kitabı'nın yeni yazması hakkında teşhis edici bir özellik taşıyan bu eser, Türkolojinin "yalım kayası" bir hoca ile, onun öğrencisi genç bir araştırmacının imzasını taşımaktadır. Her iki hocamızı da kutlar, eserleriyle ışık olmaya devam etmelerini dileriz. Tanitmacinın burada matlabı budur ki yazıcıların mürekkebi gibi bilim insanlarının da teşhis ediciliği hep var olsun söz tamamlansin.

\section{Kaynakça}

Sertkaya, O. F. (2020). Dede Korkut Kitabı Üzerine Araştırmalar ve İncelemeler. Bilge Kültür Sanat Yayınları.

Sertkaya, O. F. \& Uzuntaş, H. (2020). Dede Korkut'un Günbed Yazması Üzerine Araştırmalar ve İncelemeler. Bilge Kültür Sanat Yayınları. 